\title{
Iatrogenic Botulism
}

National Cancer Institute

\section{Source}

National Cancer Institute. Iatrogenic Botulism. NCI Thesaurus. Code C128345.

Botulism that occurs following injection of botulinum toxin. 